\title{
Tracheoesophageal fistula closed by a new gastrointestinal occluder device
}

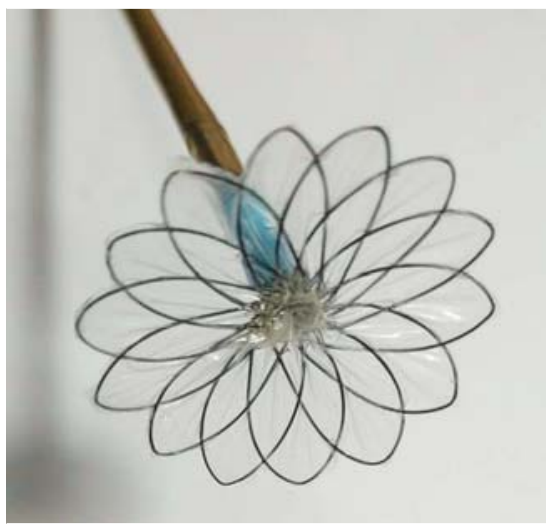

- Fig. 1 Gastrointestinal occluder device and delivery device.

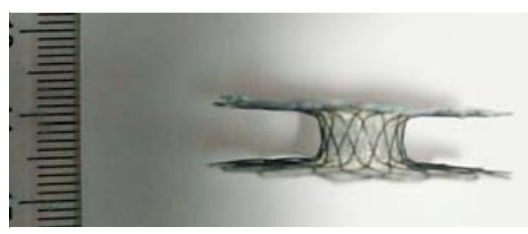

> Fig. 2 Gastrointestinal occluder device.

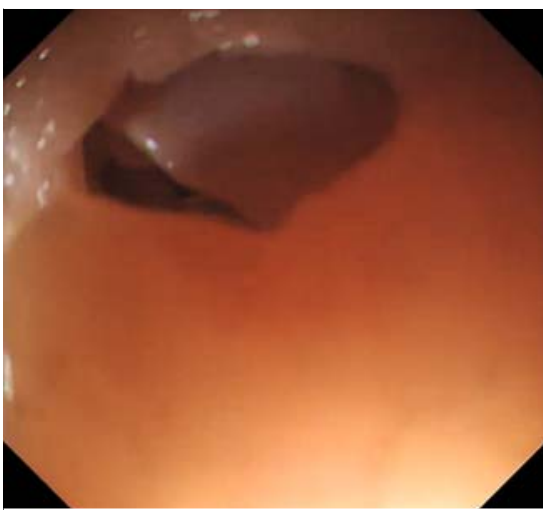

Fig. 3 Esophageal view of the fistula orifice.

Tracheoesophageal fistulas (TEFs) are pathological communications between the airway and the adjacent esophagus that can involve serious, life-threatening complications, being associated with high mortality, short survival time, and poor quality of life [1]. According to the European Society of Gastrointestinal Endoscopy Clinical Guideline, a self-ex-

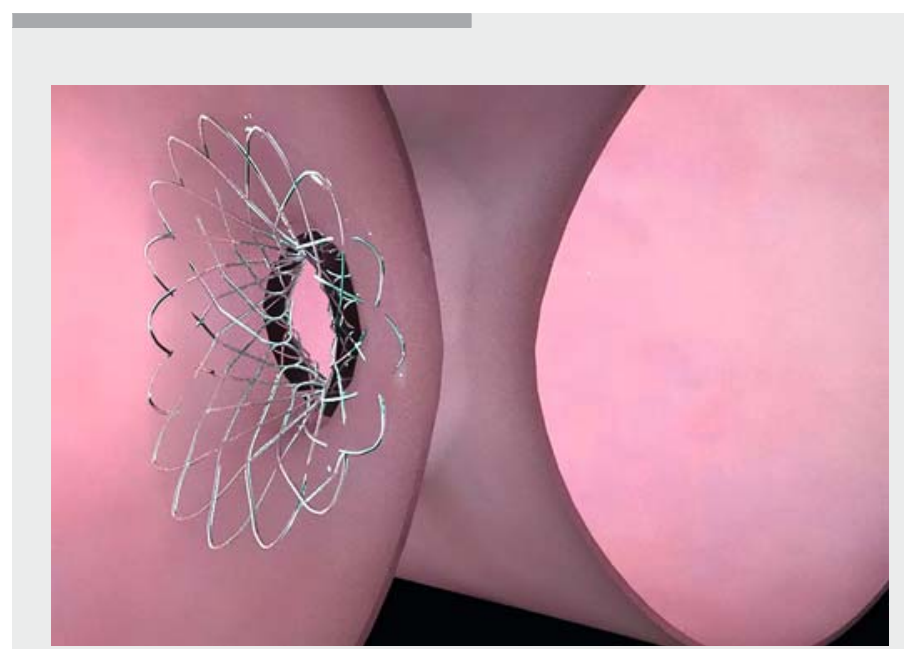

panding metal stent is the preferred treatment option [2]. However, considering the poor clinical success rate of this treatment, the chance that the fistula will reopen remains high [3]. Several previous studies have shown that, in selected patients, TEFs can be healed by an Amplatzer septal occluder (AGA Medical Corporation, Plymouth, Minnesota, USA) [1, 4]. However, Daniel et al. reported the case of a patient who died of fatal hemoptysis after closure of a benign gastrobronchial fistula with an Amplatzer device [5].

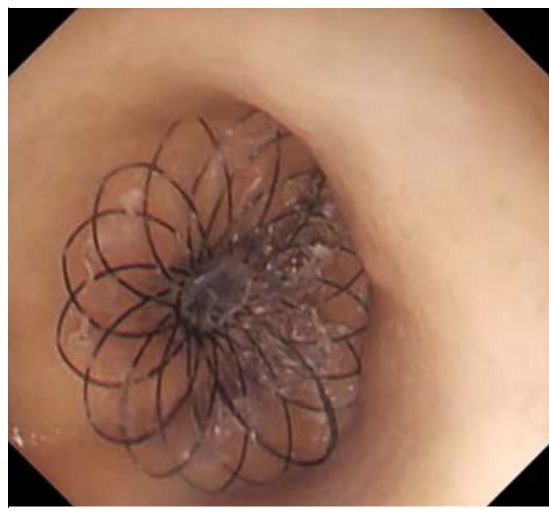

- Fig. 5 Bronchial views of the occluder device following insertion into the fistula.

Here, we propose a novel occluder device which was professionally designed for TEFs (PCT/CN2020/077659), the first to be described in the literature.

The device is made of laminated nitinol mesh with two self-expanding discs connected by a thin waist ( $\mathbf{F i g . 1 , ~}>$ Fig. 2), allowing mechanical closure of both ends of the fistula, giving a potential substrate for subsequent organized ingrowth. - Video 1 shows upper gastrointestinal endoscopy of a 5-mm fistula with positioning of the device in an in vitro 
porcine model ( $\triangleright$ Fig. 3 ). We introduced a 9-Fr catheter through the endoscope and thus were able to introduce the device into the airway. We released the distal disc under direct vision and gently pulled the device until it sat tight against the airway wall (>Fig.4). While withdrawing the sheath, we slowly pulled the cable under direct vision to release the proximal disc ( $\triangleright$ Fig.5). Once the stent was properly positioned, the cable was detached, releasing the device. Finally, we withdrew the cable and endoscope.

Compared with the Amplatzer occluder, this device may have the following advantages: (1) it has no protrusion, so even if the patient coughs, it will not damage the trachea; (2) it could be manufactured using degradable materials in future; (3) it can carry a retrieval line, and can be retrieved endoscopically if necessary. In conclusion, the use of the new device for closure of TEFs will probably provide an alternative method to mechanically close TEF defects in the future.

Endoscopy_UCTN_Code_TTT_1AO_2AI

Competing interests

The authors declare that they have no conflict of interest.
The authors

Huaiming Sang*, Lei Peng ${ }^{*}$, Guoxin Zhang

Department of Gastroenterology, First Affiliated Hospital of Nanjing Medical University, Nanjing, China

Corresponding author

\section{Guoxin Zhang, MD}

Department of Gastroenterology, First Affiliated Hospital of Nanjing Medical University, 300 Guangzhou Road, District of Gulou, Nanjing 210029, P. R. China

Fax: +86-025-83714511

guoxinz@njmu.edu.cn

\section{References}

[1] Traina M, Amata M, De Monte L et al. Chronic tracheoesophageal fistula successfully treated using Amplatzer septal occluder. Endoscopy 2018; 50: 1236-1237

[2] Spaander MC, Baron TH, Siersema PD et al. Esophageal stenting for benign and malignant disease: European Society of Gastrointestinal Endoscopy (ESGE) Clinical Guideline. Endoscopy 2016; 48: 939-948

[3] Sharma P, Kozarek R. Practice Parameters Committee of American College Of Gastroenterology. Role of esophageal stents in benign and malignant diseases. Am J Gastroenterol 2010; 105: 258-273

[4] Repici A, Presbitero P, Carlino A et al. First human case of esophagus-tracheal fistula closure by using a cardiac septal occluder (with video). Gastrointest Endosc 2010; 71: 867-869

* contributed equally to this work
[5] Buitrago DH, Pinto D, Berkowitz SJ et al. Fatal hemoptysis after closure of gastrobronchial fistula using an Amplatzer vascular device. Ann Thorac Surg 2018; 105: e71e73

Bibliography

Endoscopy 2021; 53: E203-E204

DOI 10.1055/a-1234-6702

ISSN 0013-726X

published online 11.9.2020

(c) 2020. Thieme. All rights reserved. Georg Thieme Verlag KG, Rüdigerstraße 14, 70469 Stuttgart, Germany

ENDOSCOPY E-VIDEOS

https://eref.thieme.de/e-videos

口回 Endoscopy E-Videos is a free access online section, reporting 口if: on interesting cases and new techniques in gastroenterological endoscopy. All papers include a high quality video and all contributions are freely accessible online.

This section has its own submission website at https://mc.manuscriptcentral.com/e-videos 